\title{
A kötődési jellemzők és multiimpulzív tünetek kapcsolata evészavarokban
}

\author{
Szalai Tamás Dömötör
}

Semmelweis Egyetem, Általános Orvostudományi Kar, Magatartástudományi Intézet, Budapest

\begin{abstract}
Bevezetés: A kötődési diszfunkciók meghatározzák a borderline személyiségzavart, amely a multiimpulzivitás gyakori háttértényezője. A kötődés és a multiimpulzív evészavarok kapcsolata mégis szinte feltáratlan.

Célkitüzés: Multiimpulzív és klasszikus evészavarosok, illetve evészavartól mentes személyek kötődésének összehasonlítása; továbbá feltárni, hogy a kötődés mennyire magyarázza a multiimpulzív tüneteket.

Módszer: Keresztmetszeti online kérdő́ives vizsgálat (148 nő, átlagéletkor: 30,9 év), amely e három csoportban mérte az anyai, apai és felnőtt kötődést, a depressziót, a szorongást, az evészavar- és multiimpulzív tüneteket.

Eredmények: Az evészavartól mentes csoport 41,3\%-a, a klasszikus evészavarosok 17,6\%-a, a multiimpulzív csoport 11,8\%-a biztonságosan kötődött. A legsúlyosabb evészavartünetek $\left(\mathrm{F}_{(2)}=17,733\right)$ és legalacsonyabb apai gondoskodás $\left(\mathrm{F}_{(2)}=3,443\right)$ a multiimpulzív evészavarosokat jellemezték. A kötődési aggodalmaskodás és bizalmatlanság a multiimpulzív tünetek 14,5\%-át magyarázta, ám a depresszióra korrigálva csak utóbbi bizonyult a multiimpulzivitás prediktorának $(\mathrm{t}=5,166, \mathrm{p}<0,01)$.

Következtetés: A multiimpulzív személyek tüneti és kötődési szempontból is az evészavarosok különálló csoportját alkotják. A negatív hangulatok kezelése terápiás potenciállal bírhat esetükben. Az apai gondoskodás, kötődési aggodalmaskodás, bizalmatlanság terápiás jelentőségének feltárásához longitudinális vizsgálatok szükségesek.

Orv Hetil. 2017; 158(27): 1058-1066.
\end{abstract}

Kulcsszavak: szülői kötődés, felnőtt kötődés, impulzivitás, borderline személyiségzavar, evészavar

\section{The relationship of attachment features and multi-impulsive symptoms in eating disorders}

Introduction: Attachment dysfunctions determine borderline personality disorder, which is a frequent background factor of multi-impulsivity; however, the relationship between attachment and multi-impulsive eating disorders is almost unexplored.

Aim: To compare attachment features of multi-impulsive and classical eating disorder patients with individuals without eating disorders, and to test attachment as a predictor of multi-impulsivity.

Method: A cross-sectional survey (148 females, mean age: 30.9 years) investigated maternal, paternal and adult attachment, depression, anxiety, eating disorder and multi-impulsive symptoms in these groups.

Results: Altogether $41.3 \%$ of the individuals without eating disorders, $17.6 \%$ of classical and $11.8 \%$ of multi-impulsive eating disorder patients had secure attachment. Multi-impulsive patients had the most severe eating disorder symptoms $\left(\mathrm{F}_{(2)}=17.733\right)$ and the lowest paternal care $\left(\mathrm{F}_{(2)}=3.443\right)$. Preoccupied and fearful attachment explained $14.5 \%$ of multi-impulsive symptoms; however, with adjustment for depression only latter one remained the predictor of multi-impulsivity $(\mathrm{t}=5.166, \mathrm{p}<0.01)$.

Conclusion: Multi-impulsives are a distinct subgroup of eating disorder patients from the aspects of both symptoms and attachment. Handling their negative moods may hold therapeutic potentials. Longitudinal studies are required to investigate the therapeutic value of paternal care, attachment preoccupation and fearfulness.

Keywords: parental bonding, adult attachment, impulsivity, borderline personality disorder, eating disorder

Szalai TD. [The relationship of attachment features and multi-impulsive symptoms in eating disorders]. Orv Hetil. 2017; 158(27): 1058-1066.

(Beérkezett: 2017. április 17.; elfogadva: 2017. május 16.) 


\section{Rövidítések}

$\mathrm{BMI}=($ body mass index $)$ testtömegindex CES-D = (Center for Epidemiologic Studies Depression) CES-D Depresszió Kérdő́v; DSM-V = Diagnostic and Statistical Manual of Mental Disorders - Fifth Edition; EBSS = (Eating Behavior Severity Scale) Evészavartünetek Súlyossági Skálája; EDI = (Eating Disorder Inventory) Evési Zavar Kérdőív; PBI $=($ Parental Bonding Instrument) Szülői Bánásmód Kérdőív; RSQ $=($ Relationship Scales Questionnaire) Kapcsolati Skálák Kérdoóiv; SD = standard deviation (szórás); STAI = (State-Trait Anxiety Inventory) Spielberger Szorongás Kérdőív

A gyermekkori kötődés a csecsemő és gondozója közötti elsődleges, komplementer jellegü érzelmi kapcsolat [1]. Bowlby [1] elmélete szerint a kötődés egy evolúciós alapú, veleszületett motivációs-viselkedéses rendszer, amelynek célja a túlélés és a biztonság élményének megteremtése - a gyermek és szülő közti távolság szabályozása révén. A gyermek-szülő kapcsolat tapasztalatai alapján alakul ki a kötődés belső munkamodellje, amely az én és a másik reprezentációit tartalmazza, a személyközi megismerés és viselkedésvezérlés alapjául szolgálva [1]. A kötődés befolyásolja a személyiségfejlődést, az érzelemszabályozást, a személyes és kapcsolati viselkedésdinamikát [2]. Jellemzői viszonylag stabilak, de tapasztalatok fényében változhatnak; a szülői minták hasonlíthatnak és különbözhetnek [3], így fontos az anyai, apai és felnőtt kötődés megkülönböztetése.

A felnőtt kötődést a szorongás és elkerülés dimenzióinak kombinációival jellemezhetjük [2]. A biztonságos kötődésű személyek alacsony szorongással és elkerüléssel, önmagukról és a másikról is pozitív képpel rendelkeznek. Elkerülő kötődésben alacsony a szorongás, de erős a távolságigény. Az aggodalmaskodó kötődőket magas közelségigény és alulszabályozott érzelmek, a bizalmatlan kötődést pedig magas elkerülés és szorongás jellemzi, amely kapcsolati vagy érzelemszabályozási zavarokhoz vezet $[2,4]$.

Míg a biztonságos kötődés a mentális egészség és a stabil személyiség védő tényezője, a bizonytalan kötődési típusok rontják az önértékelést, fokozhatják a stresszérzékenységet, depressziót és szorongást $[5,6]$. A diszfunkcionális kötődés fejlődéslélektani, környezeti és biológiai tényezőkkel kölcsönhatásban fokozza a pszichiátriai zavarok valószínúségét, beleértve a borderline személyiségzavart és evészavarokat $[7,8]$.

\section{Kötődés és evészavarok}

A kötődés az evészavarosok nagy részénél bizonytalan [9]. A szülői kötődést a leválás, egyénné válás nehézsége, alacsony autonómia és magas szorongás jellemzi [10, 11]. A konfliktusos szülőii kötődés hozzájárulhat a maladaptív evési attitűdökhöz [12], és a magas kalóriatartalmú ételek fogyasztásához [13]. Az evészavartünetek pedig a szülők figyelmét, közelséget hívhatják, amely rejtett kötődési motívumokra utalhat a zavar hátterében [14]. A serdülő és felnőtt evészavarosok kötődése szintén bizonytalan, fóképp a személyiségzavaros esetekben [15]. Bulimiában aggodalmaskodó, anorexiában elkerülő kötődés gyakori $[11,16]$, de az egyes evészavartípusok és kötődési minták közötti specifikus kapcsolat nem bizonyított [15]. Minél sérültebb azonban a kötődés, annál súlyosabbak a tünetek [17], illetve egyes tünetek, például falás-tisztulás (purgálás) esetén diszfunkcionálisabb lehet a kötődés [18], amely a kötődési jellemzők és az impulzív tünetek kapcsolatát sugallja.

Ennek magyarázatát részben az érzelemszabályozási stratégiák eredményességében találhatjuk, amely nagymértékben közvetíti a kötődés és evészavarok kapcsolatát [19]. Elkerülő kötődésben az érzelmek túlszabályozása, aggodalmaskodó és bizalmatlan kötődés esetén viszont alulszabályozás jellemző [2]. Maguk az evészavartünetek maladaptív érzelemszabályozási próbálkozásoknak is tekinthetőek [20]. Ugyanakkor a kötődési szorongás csökkentését célzó maladaptív viselkedések evészavarokra, hangulatzavarokra, személyiségzavarokra is hajlamosíthatnak $[19,21,22]$. E jelenségeket az evészavarok spektrumszemlélete fogja össze, amely az egyes formák hátterében tapasztalható dinamikát az úgynevezett „kompulzív-impulzív spektrum” mentén írja le. Így a kényszeres vonásokkal jellemezhető restriktív anorexia nervosától, a purgáló anorexián, bulimián át a falászavar és a több kirobbanó viselkedést mutató multiimpulzív bulimia felé halad [23].

\section{A kötődés, borderline személyiségzavar és multiimpulzív evészavar kapcsolata}

Bulimia nervosa és az anorexia nervosa purgáló típusa esetén a tünetek kialakulásában központi jelentőségü az impulzuskontroll-zavar, amely szempontjából elkülöníthetünk „uniimpulzív” (a továbbiakban „klasszikus”) és „multiimpulzív” evészavarformákat [24]. Előbbiben egyedül a falás-purgálás jelentkezik impulzív tünetként, míg multiimpulzív evészavarok esetén ez más impulzív érzelmi és viselkedéses jellemzőkkel is társul, mint [25]: 1. Nagymértékű alkohol- vagy drogfogyasztás, drogtúladagolás, önkárosítás, szexuális gátlástalanság, bolti lopás.

2. E viselkedések kontrollvesztéssel társulnak.

3. A viselkedések váltakozhatnak, impulzív jellegúek.

4. A depresszió és düh pedig akkor is jelen van a személyben, amikor viselkedését kontrollálni képes.

A multiimpulzivitás gyakran a borderline személyiségzavar talaján jelenik meg. Ezért a multiimpulzív betegek feltûnő jellemzői az evészavartünetek mellett az erősebb depresszió, szorongás, instabilabb kapcsolatok, identitás és önértékelés, úgy mint a klasszikus evészavarok esetén [23]. A multiimpulzivitás előfordulása bulimiában akár 16-80\%-os, a borderline személyiségzavarban pedig az érintettek 15-34\%-a mutat evészavartüneteket [23, 26$].$ 
A kora gyermekkori traumák és szeparációs élmények talaján megjelenő bizalmatlan, szétesett kötődés - többek között a megváltozott dopamin-, szerotonin- és neuropeptid-expresszió révén [8] - hozzájárul az intenzívebb negatív hangulatokhoz, társas és stresszérzékenységhez, fokozott agresszivitáshoz, impulzivitáshoz és érzelemszabályozási zavarokhoz [2, 9, 22, 27, 28]. A bizonytalan kötődést, elégtelen énképet és érzelemfeldolgozási deficitet a kötődési személyhez való túlzó kapcsolódás és leválás szélsőséges oszcillációja kompenzálja [21, 22]. Többek között e mechanizmusok révén a diszfunkcionális kötődési jellemzők meghatározzák a borderline személyiségzavar kialakulását, és szerepet játszanak a borderline személyiségzavarhoz kapcsolódó viselkedésdinamika fenntartásában $[8,22,27,28]$. A borderline személyiségzavar és múködés pedig gyakran megalapozza a multiimpulzív tüneteket [25]. Ennek ellenére a kötődési jellemzők és multiimpulzivitás kapcsolata evészavarokban szinte feltáratlan [29].

\section{Célkitüzés}

A vizsgálat célja ezért multiimpulzív és klasszikus evészavarosok, illetve evészavart nem mutató személyek kötődési jellemzőinek összehasonlítása volt; továbbá annak feltárása, hogy a kötődési diszfunkciók milyen mértékben magyarázzák a multiimpulzív tüneteket evészavarokban.

\section{Módszer}

A keresztmetszeti online kérdőíves vizsgálat 2015. április és 2016. június között, a Magyar Egészségügyi Tudományos Tanács Tudományos és Kutatásetikai Bizottság etikai engedélyével (56922/2015/EKU) történt. A vizsgálatban való részvétel önkéntes és anonim volt, kompenzálásra semmilyen formában nem került. A kérdőívek kitöltése előtt minden vizsgált személy - és fiatalkorúak esetén a szüleik is - írásos, tájékozott beleegyezést adtak a részvételhez.

A kérdőívet az evészavartól mentes csoport egyetemi levelezőrendszereken és szociális médiafelületeken, az evészavaros csoport DSM-V [30] a diagnosztikai interjú után a pszichiátertől vagy a klinikai szakpszichológustól kapta.

\section{Résztvevők}

Összesen 176 fótől érkeztek adatok. Ebből a 10 férfi, egy testtömegindex- (BMI-) adat nélküli, kettő evészavar diagnózissal nem rendelkező, de 17,5 alatti testtömegindexű és 15, korábban evészavarral diagnosztizált, jelenleg normális testtömegú résztvevő adatai kerültek törlésre a torzító hatások megelőzése érdekében.

A 148 nőből álló végső minta életkorátlaga 30,9 év volt $(S D=11,32$ év; 13-61 év). Testtömegindex-átlaguk
23,3 volt $(\mathrm{SD}=6,83 ; 12,7-44,8$ év $), 25,7 \%$-uk alultáplált $(\mathrm{BMI}<18,5), 41,9 \%$-uk normális testtömegú $(\mathrm{BMI}=$ $18,5-24,9), 32,4 \%$-uk pedig túlsúlyos $(\mathrm{BMI} \geq 25,0)$. Öszszesen $65,7 \%$ budapesti, $27,6 \%$ városi, $6,7 \%$ falusi lakos; 16,2\%-uk alapfokú, 30,4\% középfokú, 53,4\% felsőfokú végzettségú; 39,9\%-uk élt kapcsolatban. A minta három csoportra oszlott:

1. Evészavartól mentes csoport: 80 fó $(54,1 \%)$; beválogatási kritériumuk, hogy nincs evészavar diagnózis, vagy kezelés, 17,5 feletti BMI, és kevesebb mint 14 pontot értek el az Evési Zavar Kérdőív Bulimia alskáláján.

2. Klasszikus evészavar csoport: 51 fó $(34,5 \%)$; kritériumaik az anorexia nervosa, bulimia nervosa, falászavar, egyéb evészavar diagnózis [30]; korábbi evészavar diagnózis és jelenleg 17,5 alatti BMI vagy jelentős bulimiás tünetek [31]; valamint maximum két multiimpulzív tünet.

3. Multiimpulzív evészavar csoport: 17 fö $(11,5 \%)$; kritériuma a fenti evészavar diagnózisok mellett legalább három multiimpulzív tünet jelenléte - Myers és mtsai alapján [24].

\section{Mérőeszközök}

Szociodemográfiai és antropometriai adatok: kor, lakóhely, végzettség, testmagasság (cm), testtömeg $(\mathrm{kg})$, kalkulált BMI $\left(\mathrm{kg} / \mathrm{m}^{2}\right)$.

Evési Zavar Kérdóív (EDI) [31, 32]: az anorexia, bulimia tüneteit és az anorexia kognitív jellemzőit méri 64 tétellel, nyolc skálával. A Karcsúság iránti késztetés (Cronbach- $\alpha=0,92)$, Testtel való elégedetlenség (Cronbach- $\alpha=0,78)$ és Bulimia (Cronbach- $\alpha=0,91$ ) skálák kerültek elemzésre.

Evészavartünetek Súlyossági Skálája (EBSS) [31, 33]: hét tétellel méri a falás, hányás, hashajtók, diuretikumok, étvágycsökkentők, diétázás, edzés gyakoriságát az elmúlt három hónapban. Az evészavartünetek súlyosságát a skála összesített pontszáma, a purgálást pedig az önhánytatás, hashajtók, diuretikumok pontszáma jelzi. Cronbach- $\alpha$ együtthatója 0,56 volt.

Kapcsolati Skálák Kérdőív (RSQ) [4, 34]: 30 tétellel méri a felnőtt kötődés biztonságosság, elkerülés, aggodalmaskodás és bizalmatlanság dimenzióit. Kötődési típusokba az alskálák standardizált válaszátlagainak sorrendje alapján sorolhatóak a személyek. Más vizsgálatokhoz hasonlóan [34] a Cronbach- $\alpha$ együtthatók alacsonyak voltak. A bizalmatlan kötődés 0,69 , az aggodalmaskodó 0,45 , az elkerülő 0,58 , a biztonságos csak 0,34 . Utóbbi skálából ezért a 10. tételt szelektáltuk, így a Cronbach- $\alpha$ 0,48-ra nött.

Szülői Bánásmód Kérdőív (PBI) $[35,36]$ : 25-25 tétellel méri az első 16 életév anyai és apai bánásmódjának két dimenzióját: a Szülői gondoskodás a törődés vagy közömbösség, a Túlvédés pedig az autonómia vagy túlvédés mértékét. Az anyai gondoskodás Cronbach- $\alpha$ együtthatója 0,94 , az apai gondoskodásé 0,95 , az anyai túlvédésé 0,91, az apai túlvédésé 0,90 volt. 


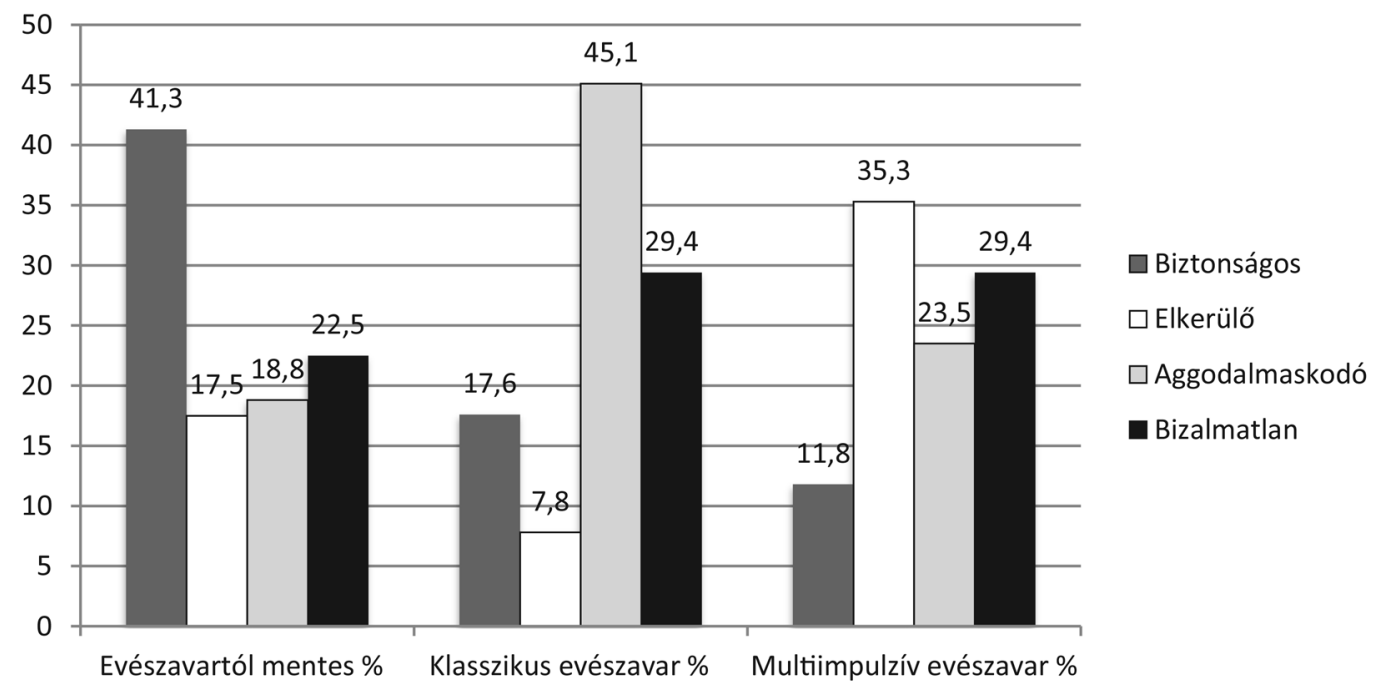

1. ábra

A felnőtt kötődési minták egyes csoportokon belüli százalékos gyakorisága

Megjegyzés: evészavartól mentes csoport = 80 fó, klasszikus evészavaros = 51 fó, multiimpulzív evészavaros $=17$ fó.

Multiimpulzív tünetek: Lacey és Evans [25] alapján 11 tétellel mértük az alkohol- és droghasználatot vagy túladagolást, önsértést, lopást, dühöt, depressziós hangulatot és kontrollvesztést. A multiimpulzivitás feltételeként minimum három tünetet határoztunk meg [24]. A skála Cronbach- $\alpha$ együtthatója 0,81 .

Center for Epidemiologic Studies Depression (CESD) $[34,37]: 20$ tételes, a depresszió tüneteinek elmúlt heti intenzitását mérő kérdőív; Cronbach- $\alpha$ együtthatója 0,93 volt.

Spielberger Szorongás Kérdőív (STAI) [38, 39]: 20 tételes, állapot- és vonásszorongást mérő kérdốiv. A vizsgálatban a vonásszorongás került mérésre; a Cronbach- $\alpha$ 0,93 volt.

\section{Adatelemzés}

A skálák megbízhatóságának mérésére Cronbach- $\alpha$ együtthatókat, az átlagok, szórás és Spearman-féle korrelációk mérésére leíró statisztikát alkalmaztunk. A kötődési típusok gyakorisága $\chi^{2}$-próbával, az evészavartól mentes, klasszikus és multiimpulzív evészavaros csoportok pedig egyszempontos varianciaanalízissel kerültek összehasonlításra. A multiimpulzivitás prediktorait többszörös lineáris logisztikus regresszióelemzéssel, enter módszerrel teszteltük az IBM SPSS 23.0 segítségével.

\section{Eredmények}

A teljes minta $29,7 \%$-a volt biztonságos, 16,2\%-a elkerülő, 28,4\%-a aggodalmaskodó, 25,7\%-a bizalmatlan felnőtt kötődésú. A $\chi^{2}$-próba alapján a kötődési minták gyakorisága eltért a csoportokban $\left(\chi^{2}(6)=22,485\right.$, Cramer
$\mathrm{V}=0,276 ; \mathrm{p}=0,001)$. Az evészavartól mentes személyek 41,3\%-a, a klasszikus evészavarosok 17,6\%-a, míg a multiimpulzívok csak 11,8\%-a volt biztonságos kötődésű (1. ábra).

Az egyszempontos varianciaanalízis alapján az evészavartól mentes csoportnál súlyosabb tünetek jellemezték a klasszikus, és náluk is intenzívebbek a multiimpulzív evészavarosokat. A multiimpulzív csoport átlagéletkora és testtömegindexe alacsonyabb volt, mint az evészavartól mentes személyeké, falás, purgálás, bulimiás és impulzív tüneteik pedig gyakoribbak, mint a többi két csoportban. Az apai gondoskodás lényegesen alacsonyabb volt a multiimpulzív, mint a többi két csoportban. A klasszikus és multiimpulzív evészavarosok kötődése bizonytalanabb, bizalmatlanabb, karcsúság iránti késztetésük, testtel való elégedetlenségük, depresszió- és szorongásszintjük magasabb volt, mint az evészavartól mentes személyeké, de az evészavarosok e téren nem különböztek jelentősen (1. táblázat).

A Spearman-féle korrelációelemzés alapján a multiimpulzív tünetek együttjártak a felnőtt kötődés bizonytalanságával $(0,282)$, bizalmatlanságával $(0,378)$, az anyai $(0,186)$ és apai $(0,180)$ gondoskodás alacsonyabb fokával. Továbbá a multiimpulzivitás korrelált a karcsúság iránti késztetés $(0,436)$, testtel való elégedetlenség $(0,330)$, bulimia $(0,539)$, falás $(0,450)$, purgálás $(0,378)$, depresszió $(0,576)$ és szorongás intenzitásával $(0,529)$. A többszörös lineáris regresszióelemzés alapján csak az aggodalmaskodás és bizalmatlanság kötődési dimenziói voltak a multiimpulzivitás előrejelzói (első modell). A második modellt korra, BMI-re, depresszióra, szorongásra korrigálva pedig egyedül a depresszió szintje bizonyult a multiimpulzív tünetek prediktorának, a kötődés elvesztette magyarázóerejét (2. táblázat). 
1. táblázat |Az evészavartól mentes, klasszikus és multiimpulzív evészavaros csoportok összehasonlítása.

\begin{tabular}{|c|c|c|c|c|}
\hline Változó & $\begin{array}{l}\text { Evészavartól mentes } \\
(\mathrm{n}=80 \text { fó) }\end{array}$ & $\begin{array}{l}\text { Klasszikus evészavaros } \\
(\mathrm{n}=5 \mathrm{l} \text { fó })\end{array}$ & $\begin{array}{l}\text { Multiimpulzív } \\
\text { evészavaros } \\
(\mathrm{n}=17 \text { fó) }\end{array}$ & $\begin{array}{l}\text { A csoportok } \\
\text { összehasonlítása }\end{array}$ \\
\hline Kor, átlag (SD) & $34,4(11,24)$ & $27,2(10,89)$ & $25,3(6,67)$ & $\mathrm{F}_{(2)}=9,683^{* * *}$ \\
\hline BMI, átlag (SD) & $25,3(6,51)$ & $21,1(6,97)$ & $20,4(4,71)$ & $\mathrm{F}_{(2)}=8,538^{* * *}$ \\
\hline Biztonságosság, átlag (SD) & $3,2(0,80)$ & $2,5(0,80)$ & $2,7(0,63)$ & $\mathrm{F}_{(2)}=12,418 * * *$ \\
\hline Elkerülés, átlag (SD) & $3,4(0,71)$ & $3,5(0,70)$ & $3,7(0,66)$ & $\mathrm{F}_{(2)}=1,301$ \\
\hline Aggodalmaskodás, átlag (SD) & $3,2(0,73)$ & $3,4(0,90)$ & $3,4(0,64)$ & $\mathrm{F}_{(2)}=1,552$ \\
\hline Bizalmatlanság, átlag (SD) & $2,9(0,99)$ & $3,3(0,92)$ & $3,53(0,91)$ & $\mathrm{F}_{(2)}=4,569^{*}$ \\
\hline Anyai gondoskodás, átlag (SD) & $24,9(9,25)$ & $26,3(8,86)$ & $21(8,49)$ & $\mathrm{F}_{(2)}=2,256$ \\
\hline Apai gondoskodás, átlag (SD) & $20,6(10,01)$ & $20,1(9,79)$ & $13,6(10,65)$ & $\mathrm{F}_{(2)}=3,443^{*}$ \\
\hline Anyai túlvédés, átlag (SD) & $14,8(8,23)$ & $16,6(9,33)$ & $14,7(9,51)$ & $\mathrm{F}_{(2)}=0,747$ \\
\hline Apai túlvédés, átlag (SD) & $12,7(8,26)$ & $12,6(8,23)$ & $15,8(10,54)$ & $\mathrm{F}_{(2)}=1,037$ \\
\hline Karcsúság iránti késztetés, átlag (SD) & $5,8(6,28)$ & $11,7(6,15)$ & $14,9(6,12)$ & $\mathrm{F}_{(2)}=22,998 * * *$ \\
\hline Testtel való elégedetlenség, átlag (SD) & $9,4(8,01)$ & $12,7(6,90)$ & $15,8(8,49)$ & $\mathrm{F}_{(2)}=6,160^{* *}$ \\
\hline Evészavartünetek súlyossága, átlag (SD) & $6,4(4,63)$ & $9,7(5,71)$ & $14,2(6,24)$ & $\mathrm{F}_{(2)}=17,733^{* * *}$ \\
\hline Bulimiatünetek, átlag (SD) & $2,5(3,67)$ & $4,1(5,01)$ & $8,5(5,65)$ & $\mathrm{F}_{(2)}=13,798 * * *$ \\
\hline Falás, heti átlag (SD) & $0,19(0,39)$ & $0,37(0,49)$ & $0,76(0,44)$ & $\mathrm{F}_{(2)}=13,093^{* * *}$ \\
\hline Purgálás, heti átlag (SD) & $0,1(0,38)$ & $0,3(0,53)$ & $0,7(0,59)$ & $\mathrm{F}_{(2)}=12,448 * * *$ \\
\hline Multiimpulzív tünetek, átlag (SD) & $1,1(1,46)$ & $0,8(0,87)$ & $4,5(1,66)$ & $\mathrm{F}_{(2)}=56,308 * * *$ \\
\hline Depresszió, átlag (SD) & $17,5(11,78)$ & $25,2(12,04)$ & $31,4(12,42)$ & $\mathrm{F}_{(2)}=12,700 * * *$ \\
\hline Vonásszorongás, átlag (SD) & $46,2(11,38)$ & $53,5(8,84)$ & $60,0(4,36)$ & $\mathrm{F}_{(2)}=17,461 * * *$ \\
\hline
\end{tabular}

Megjegyzés: ${ }^{*} \mathrm{p}<0,05 ;{ }^{*} \mathrm{p}<0,01 ;{ }^{*}{ }^{*} \mathrm{p}<0,001$

$\mathrm{n}=\mathrm{az}$ adott csoport elemszáma; $\mathrm{SD}=$ szórás

2. táblázat |A multiimpulzivitás prediktorai

\begin{tabular}{llllll}
\hline \multicolumn{5}{c}{ Multiimpulzív tünetek* } \\
\hline & Prediktor & $\beta(95 \%$-os & t & $\mathrm{p}$ & $\mathrm{R}^{2}$ \\
& & $\mathrm{CI})$ & & & \\
\hline Első & Aggodalmaskodás & 0,579 & 2,635 & $0,009^{* * *}$ & \\
modell & (RSQ) & $(0,310 ;$ & & & \\
& & $0,848)$ & & & \\
& Bizalmatlanság & 0,446 & 4,254 & $0,000^{* * *}$ & 0,145 \\
& (RSQ) & $(0,112 ;$ & & & \\
& & $0781)$ & & & \\
\hline Második & Aggodalmaskodás & 0,051 & 0,292 & 0,771 & \\
modell & (RSQ) & $(-0,293 ;$ & & & \\
& & $0,394)$ & & & \\
& Bizalmatlanság & 0,227 & 1,587 & 0,115 & \\
& (RSQ) & $(-0,056 ;$ & & & \\
& & $0,509)$ & & & \\
& Depresszió & 0,061 & 5,166 & $0,000^{* * *}$ & 0,279 \\
& (CESD) & $(0,038 ;$ & & & \\
& & $0,084)$ & & & \\
\hline
\end{tabular}

Megjegyzés: $\mathrm{n}=148$; *Lacey és Evans [25] 11 tünetének gyakorisága; ${ }^{* * *} \mathrm{p}<0,001 ; \mathrm{R}^{2}=$ Nagelkerke $\mathrm{R}^{2}$ a teljes modellre

CESD = Center for Epidemiologic Studies Depression; RSQ = Kapcsolati Skálák Kérdőív; SD = szórás

\section{Megbeszélés}

Míg az evészavartól mentes személyek majdnem fele, a klasszikus evészavarosok alig egyötöde és a multiimpulzívok csak egytizede volt biztonságos kötődésû. Ez egybevág a biztonságos kötődés körében más evészavarvizsgálatokban is kimutatott $10-15 \%$-os gyakorisággal [17]. Mindkét evészavarcsoport egyharmadát jellemezte bizalmatlan kötődés, de klasszikus evészavarosok főképp aggodalmaskodó, a multiimpulzív személyek fóképp elkerülő kötődésúek voltak. E kötődési dimenziók több vizsgálat szerint kapcsolódnak az evészavartünetekhez $[40,41]$, ugyanakkor az eredmények függnek a minták összetételétôl [18]. Az aggodalmaskodás mértéke differenciálhat az egészséges személyek és klasszikus evészavarosok kötődése közt [42], megerősítve az aggodalmaskodó kötődés gyakoriságát a klasszikus evészavaros csoportban. Az elkerülő kötődés gyakori előfordulását a multiimpulzív csoportban a borderline személyek dezorganizált gyermekkori kötődése, későbbi bizalmatlansága és dominálástól való félelme magyarázhatja $[8,21,22]$. Mivel a multiimpulzív csoport 35\%-a alultáplált volt, és anorexiában szintén erôs az elkerülés [11], az elkerülő 
kötődés és a multiimpulzív jegyek a purgáló anorexia hátterén is kapcsolódhattak e mintán.

$\mathrm{Az}$ eredményeket árnyalja, hogy míg a két evészavarcsoport felnőtt kötődése eltért az evészavartól mentes személyekétől, egymástól nem különbözött jelentősen. Egybecsengően, evészavarosok és más pszichiátriai betegek felnőtt kötődése sem különbözik egymástól, de a pszichiátriai zavarokat nem mutató személyekétől nagymértékben - ami a kötődési diszfunkciók általános pszichiátriai rizikófaktor jellegét sugallja [14].

$\mathrm{Az}$ apai gondoskodás különösen alacsony foka azonban mindkét csoporttól megkülönböztette a multiimpulzív evészavarosokat. A multiimpulzivitás kismértékben együttjárt az anyai és apai gondoskodás alacsonyabb fokával, a felnőtt kötődés bizonytalanságával és közepes mértékben a felnőtt kötődés bizalmatlanságával. Jelen eredményekkel egybehangzóan több vizsgálat támasztja alá a borderline személyiségzavarosok későbbi pszichopatológiáját meghatározó korai traumatizáltságot és szülői kötődési problémákat $[8,21,22]$. A borderline evészavarosok megoldatlan veszteségekkel és erősebb szülők iránti haraggal jellemezhetők, mint a klasszikus evészavarosok [29]. Alacsonyabb szülői törődés és magasabb túlvédés jellemzi őket, az apai bánásmód alakulása pedig terápiás szempontból is meghatározó [23]. Tehát a multiimpulzív személyek a - szülői - kötődés szempontjából is az evészavarosok egy külön csoportját jelenthetik. E viszonylag rejtett terület feltárása, fejlesztése ezért jelentős lehet a multiimpulzív kliensek megértése és eredményes támogatása szempontjából.

A multiimpulzív személyek további megkülönböztető jegyének bizonyultak a legsúlyosabb falási, purgálási és bulimiatünetek, amelyeket alátámaszthat, hogy mindhárom impulzív viselkedés [23, 24]. Más vizsgálatok [43] szintén igazolták a borderline személyiségzavar és faláspurgálás kapcsolatát, valamint a személyiségzavaros evészavarosok erôsebb tüneteit. Ennek hátterében a személyiségzavart és evészavart is dinamizáló érzelemszabályozási zavar állhat $[20,27]$. A multiimpulzív evészavarosok alacsonyabb átlagéletkorát a személyiségzavarok fiatal felnőttkori kezdete [21] magyarázhatja, alacsonyabb testtömegindexüket pedig jó eséllyel intenzívebb purgáló magatartásuk eredményezheti. A multiimpulzivitás nagymértékű együttjárása a magasabb depresszióés vonásszorongásszinttel, valamint a klasszikus és multiimpulzív evészavarosok evészavartól mentes csoportnál magasabb depresszió- és szorongásszintje a klasszikus evészavarokban és borderline személyiségzavarban szintén magas komorbiditású szorongásos és depresszív állapotok tükröződése lehet $[22,26,31]$.

A multiimpulzív tünetek és a testtel való elégedetlenség, karcsúság iránti késztetés közepes mértékű együttjárását többek között módszertani okok magyarázhatják, mivel az impulzív viselkedéseket és evészavartüneteket egyaránt félig evészavaros mintán mértük fel. E tünetek korrelációja ezért a mintavétel sajátosságaiból, az átfedő tüneti képből és a közös háttérszemélyiségből is fakad- hat. Az evészavarosok akár 62\%-ánál is diagnosztizálható személyiségzavar, ugyanakkor a restriktív és purgáló tünetek hátterében álló személyiség nagyban eltérhet [44]. Restriktív anorexiában az elkerülő személyiségzavar, kényszeres jegyek, merevség és perfekcionizmus járulnak hozzá a tünetek fennmaradásához. Purgáló anorexiában és bulimiában pedig a borderline személyiségzavar gyakori; a tüneteket és terápiás kapcsolatot az érzelmi instabilitás és impulzivitás alapozzák meg [44]. A multiimpulzív evészavarosok betegvezetésekor ezért kiemelten fontos az érzelmi instabilitás, intenzív düh, ürességérzet, szorongás és visszatérő depresszív hangulatok kezelése a tünetek romlása és a visszaesés megelőzésének érdekében. Az instabil identitásból, intenzív kötődési dinamikából és impulzív karakterjegyekből fakadóan erős, csapongó érzelmek, indulatok jelenhetnek meg az orvos-beteg kapcsolatban, amelyek megfelelö kezelése a beteggel fenntartott compliance olykor nehéz, de alapvető feltétele.

A kötődési dimenziók közül csak a felnőtt aggodalmaskodás és a bizalmatlanság magasabb foka jelezte előre az intenzívebb multiimpulzív tüneteket. Aggodalmaskodás esetén az énkép, bizalmatlanság esetén az énről és másikról kialakított kép is negatív - csakúgy, mint a borderline kliensek esetén $[4,21]$. Diszfunkcionális kötődés esetén csökkent a frusztrációs tolerancia és az érzelemfelismerési képesség [6, 45]. A konfliktusos helyzetek aggodalmaskodó és bizalmatlan kötődésben érzelmi és viselkedéses hiperaktivációhoz vezethetnek [21]. Ez csökkenti az érzelemszabályozási képességet, és rontja az adaptív megküzdési mechanizmusokat [2] - így hozzájárulva az impulzív tünetekhez [27, 45]. Továbbá az evészavarosok multiimpulzív tüneteit nagymértékben magyarázza a gyermekkori traumatizáltság [46], amelynek hatását a kötődési jellemzők közvetítik evészavarokra [41]. A kötődés diszfunkciói emellett hozzájárulhatnak a multiimpulzív tüneteket megalapozó személyiségszerveződés kialakulásához is [23,27]. Tehát a kötődési diszfunkciók és multiimpulzivitás kapcsolata több szinten alátámasztott; jóllehet, a kötődés a tünetek mindöszsze 14,5\%-át magyarázta. Ezért, bár a multiimpulzivitás és több evészavar tünettana átfed, multikauzális etiológiájuk valószínúleg csak néhány faktorban kapcsolódhat.

Ilyen alapvető tényező lehet a hangulatzavar, mivel a depresszió szintjére korrigálva a kötődési jellemzők elvesztették magyarázóerejüket, és csak a depresszió szintje maradt a multiimpulzivitás előrejelzője, a tünetek 27,9\%-át magyarázva. Részben közös etiológiájú zavarokra utalhat a szerotonerg érintettség $[8,31]$, valamint az evészavarok és borderline személyiségzavar esetén egyaránt magas komorbiditás a depresszióval $[5,26]$. Egy másik, klinikai szempontból jelentős értelmezési lehetőség, amely a kötődés magyarázóerejének csökkenését magyarázhatja, hogy a kötődési diszfunkciók és multiimpulzivitás közötti kapcsolatot a negatív hangulatok közvetítik. Ezt alátámasztó tény, hogy a diszfunkcionális kötődés fokozza a depresszív tüneteket [5] és az érze- 
lemszabályozási zavarokat, fiziológiai és pszichológiai szinten is [20]. A diszfunkcionális kötődés a negatív hangulatok és impulzivitás közvetítésével kapcsolódik a borderline személyiségzavarhoz [28], éppúgy, ahogy a kötődés és az evészavarok kapcsolatát is a depresszió szintje és az érzelemszabályozás minősége mediálja [18, 19].

Fejlődéslélektani alapon feltételezhető, hogy a diszfunkcionális kötődés hozzájárul a borderline személyiségzavar kialakulásához, amely sok esetben megalapozza a multiimpulzív tüneteket. Tehát a diszfunkcionális kötődési jellemzőknek - többek között a negatív hangulatok mediálásával - szerepük lehet a multiimpulzív viselkedésdinamika kialakulásában, fenntartásában.

Ugyanakkor jelen eredményeket a vizsgálat korlátainak fényében értelmezhetjük, és a keresztmetszeti elrendezés alapján ok-okozati következtetéseket nem vonhatunk le. A kötődési jellemzők részben nem tudatos minősége [8], az RSQ alskáláinak más vizsgálatokhoz hasonlóan alacsony belső konzisztenciája [34] és az önbevallásos adatok befolyásolhatják az eredmények megbízhatóságát. A válasz-visszautasítási ráta hiánya, a kényelmi mintavétel hordozta önszelekciós torzítás és a multiimpulzív evészavaros csoport alacsony elemszáma korlátozzák az általánosíthatóságot. Bár több szignifikáns összefüggést találtunk, hatásméret-mutatójuk általában közepes volt. A diszfunkcionális kötődés és a depresszió szintje is a multiimpulzív tünetek kis részét magyarázták, amely felhívja a figyelmet a jelenség komplex voltára.

\section{Következtetések és terápiás meggondolások}

A kötődési, érzelemfeldolgozási és személyiségzavartól szenvedő evészavarosok kevésbé reagálnak a hagyományos, tünetfókuszú eljárásokra [24]. Így az egyik legnagyobb terápiás kihívást az evészavarok ellátásában a mindhárom területen diszfunkciókat mutató multiimpulzív kliensek támogatása jelenti. Jelen eredmények megerősítik, hogy a multiimpulzív személyek a tünetek intenzitásának, a kötődés jellemzőinek és a hangulatzavar szempontjából is az evészavarok különálló csoportját alkotják. A diagnózisalkotás és terápiás folyamatok megtervezése során emiatt kulcsfontosságú lehet az evészavarok vonásalapú megközelítése, amely a tünetek mellett a személyiségjegyeket, érzelmi instabilitást, impulzivitást, kapcsolati zavarokat is figyelembe veszi [9, 24].

Kötődés szempontjából a multiimpulzív kliensek egyik fó megkülönböztetője a megélt apai gondoskodás rendkívül alacsony foka. Ezért az egyéni esetkonceptualizációk fontos, feltárandó pontja lehet a multiimpulzív kliensek által megélt szülői - elsősorban apai - törődés, amelynek fejlesztése más vizsgálatok alapján is terápiás relevanciával bírhat [23]. Az apák fokozott bevonása, motiválása és a multiimpulzív tünetekkel küzdő lányuk- kal való kapcsolat facilitálása ezért az evészavarok háziorvosi és családterápiás ellátásának színterein kiemelt szerepet érdemel.

Mivel a diszfunkcionális kötődés erősíti az impulzivitást [45], és a felnőtt kötődési aggodalmaskodás, bizalmatlanság a multiimpulzív tünetek prediktorának bizonyult, a diszfunkcionális kötődésü evészavarosok számára fontos lehet az elsődleges kötődési személlyel kapcsolatos tárgyreprezentációk felmérése, a szorongás, bizalmatlanság és ambivalencia csökkentése. Borderline személyiségzavarban és a legtöbb evészavaros esetén sérültek az érzelemreprezentációk, figyelmi funkciók és mentalizációs kapacitás, tehát az én és másik gondolatainak, érzelmeinek felismerése [21, 41], amelyeket az evészavarokban alkalmazott kötődési intervenciók is céloznak [9]. A multiimpulzín evészavarosok számára fontos kötödési intervenciós pontok lehetnek ezért a mentalizáció és a reflektív készségek fejlesztése, a kötődési stresszorok azonosítása, valamint a maladaptív kötődési stresszcsökkentő viselkedések megelőzése [10, 41, 47]. A kötődési diszfunkciókat célzó konkrét technikákat jelenthetnek az énról és a másiktól kialakított kép tudatosítása és árnyalása, a társas naplózás, a kötődési személyekkel kapcsolatos automatikus gondolatok korrekciója, tüneti gráf rajzoltatása és az önbecsülés fejlesztése [47]. A reflektív funkciók erősödése és a kötődés biztonságosabbá válása borderline személyiségzavar és evészavarok esetében is pozitív terápiás kimenetellel jár [41, 48].

Jelen eredmények mindemellett a depresszió szintjének elsődleges szerepét hangsúlyozzák a multiimpulzivitásban. Feltételezhető, hogy a multiimpulzív magatartásformák a negatív hangulati állapotoktól való megszabadulás azonnali szükségletéből erednek, maladaptív megküzdési módokhoz vezetve. Ez alapján a multiimpulzív kliensek egyik alapvető támogatási eszköze a frusztrációs tolerancia és a negativ hangulatok kezelési képességének fejlesztése, beleértve a félelem, harag, önutálat élményeinek szabályozását $[9,45]$. A gyakorló orvosok, pszichológusok számára kapcsolódó intervenciós pontokat jelenthetnek a feszültségmonitorozás, a negatív érzések felismerése és csillapítása, a hangulatjavító aktivitások keresése, valamint az érzelmi és viselkedéses hiperaktiváció ellensúlyozása [2,47]. Az érzelmek szabályozásának képességét fejlesztheti a szituációk tudatos megválasztása, megváltoztatása, az elemző figyelem, az irracionális gondolatok korrekciója és a viselkedéses válaszok megváltoztatása - amely csökkenti a negatív érzéseket, és a kapcsolati múködést is segíti $[49,50]$.

A diszfunkcionális kötődési jellemzők, kapcsolati élmények feltehetően az intenzív negatív hangulatok előidézésén keresztül kapcsolódhatnak a multiimpulzív tünetekhez. Annak ellenőrzésére azonban, hogy az alacsony apai gondoskodás, a felnőtt kötődési aggodalmaskodás, bizalmatlanság mennyiben járulhatnak hozzá a multiimpulzív evészavarosok depresszív hangulataihoz, egyéni esetkonceptualizációk, nagymintás útelemzéses és longitudinális vizsgálatok szükségesek. A kötődési inter- 
venciók alkalmazásának hatékonyságvizsgálata a multiimpulzív evészavarosok kezelésében új kutatásokat ösztönözhet.

Anyagi támogatás: A szerző az Emberi Erőforrások Minisztériuma UNKP-16-3 kódszámú Új Nemzeti Kiválósági Programjának ösztöndíjában részesült.

A szerző a cikk végleges változatát elolvasta és jóváhagyta.

Érdekeltségek: A szerzőnek nincsenek érdekeltségei.

\section{Köszönetnyilvánítás}

A szerző köszönetét fejezi ki Dr. Czeglédi Editnek az adatbázis-kezelésben nyújtott segítségéért.

\section{Irodalom}

[1] Bowlby J. The making and breaking of affectional bonds. I. Aetiology and psychopathology in the light of attachment theory. An expanded version of the Fiftieth Maudsley Lecture, delivered before the Royal College of Psychiatrists, 19 November 1976. Br J Psychiat. 1977; 130: 201-210.

[2] Mikulincer M, Shaver PR, Pereg D. Attachment theory and affect regulation: The dynamics, development, and cognitive consequences of attachment-related strategies. Motivation and Emotion 2003; 27: 77-102.

[3] Fraley CR. Attachment stability from infancy to adulthood: Meta-analysis and dynamic modeling of developmental mechanisms. Pers Soc Psychol Rev. 2002; 6: 123-151.

[4] Griffin D, Bartholomew K. Models of the self and others: fundamental dimensions underlying measures of adult attachment. J Pers Soc Psychol. 1994; 67: 430-445.

[5] Lee A, Hankin BL. Insecure attachment, dysfunctional attitudes, and low self-esteem predicting prospective symptoms of depression and anxiety during adolescence. J Clin Child Adol Psychol. 2009; 38: 219-231

[6] Maunder RG, Hunter JJ. Attachment relationships as determinants of physical health. J Am Acad Psychoanal Dyn Psychiatry 2008; 36: 11-32.

[7] Lenkiewicz K, Srebnicki T, Bryńska A. Mechanisms shaping the development of personality and personality disorders in children and adolescents. Psychiatr Pol. 2016; 50: 621-629.

[8] Steele H, Siever L. An attachment perspective on borderline personality disorder: Advances in gene-environment considerations Curr Psychiatry Rep. 2010; 12: 61-67.

[9] Tasca GA, Balfour L. Attachment and eating disorders: A review of current research. Int J Eat Disord. 2014; 47: 710-717.

[10] Kuipers GS, van Loenhout Z, van der Ark LA, et al. Attachment insecurity, mentalization and their relation to symptoms in eating disorder patients. Attach Hum Dev. 2016; 18: 250-272.

[11] Zachrisson HD, Skårderud F. Feelings of insecurity: Review of attachment and eating disorders. Eur Eat Disord Rev. 2010; 18: 97-106.

[12] Milan S, Acker JC. Early attachment quality moderates eating disorder risk among adolescent girls. Psychol Health 2014; 29: 896-914.

[13] Faber A, Dubé L. Parental attachment insecurity predicts child and adult high-caloric food consumption. J Health Psychol. 2015; 20: 511-524.
[14] Orzolek-Kronner C. The effect of attachment theory in the de velopment of eating disorders: Can symptoms be proximityseeking? Child Adol Soc Work J. 2002; 19: 421-435.

[15] Gander M, Sevecke K, Buchheim A. Eating disorders in adolescence: attachment issues from a developmental perspective. Front. Psychol. 2015; 6: 1136. Published online 2015 Aug 10. doi: 10.3389 /fpsyg.2015.01136

[16] Ringer F, Crittenden PM. Eating disorders and attachment: The effects of hidden family processes on eating disorders. Eur Eat Disord Rev. 2007; 15: 119-130.

[17] O'Shaughnessy R, Dallos R. Attachment research and eating disorders: A review of the literature. Clin Child Psychol Psychiatry 2009; 14: 559-574.

[18] Illing V, Tasca GA, Balfour L, et al. Attachment insecurity predicts eating disorder symptoms and treatment outcomes in a clinical sample of women. J Nerv Ment Dis. 2010; 198: 653-659.

[19] Tasca GA, Szadkowski L, Illing V, et al. Adult attachment, depression, and eating disorder symptoms: The mediating role of affect regulation strategies. Pers Indiv Differ. 2009; 47: 662-667.

[20] Van Durme K, Braet C, Goossens L. Insecure attachment and eating pathology in early adolescence: Role of emotion regulation. J Early Adolesc. 2015; 35: 54-78.

[21] Bateman A, Fonagy P. Psychotherapy for borderline personality. Oxford University Press, Oxford, 2005.

[22] Fonagy P. Attachment and borderline personality disorder. J Am Psychoanal Assoc. 2000; 48: 1129-1146.

[23] Lobera IJ. Bulimia nervosa and personality: A review, new insights into the prevention and treatment of bulimia nervosa. In: Hay Ph. (ed.) New insights into the prevention and treatment of bulimia nervosa. Intech Open, Rijeka, 2011; pp. 127-146.

[24] Myers TC, Wonderlich SA, Crosby R, et al. Is multiimpulsive bulimia a distinct type of bulimia nervosa: psychopathology and EMA findings. Int J Eat Disord. 2006; 39: 655-661.

[25] Lacey JH, Evans CD. The impulsivist: a multi-impulsive personality disorder. Br J Addict. 1986; 81: 641-649.

[26] Zanarini MC, Frankenburg FR, Hennen J, et al. Axis I comorbidity in patients with borderline personality disorder: 6-year follow-up and prediction of time to remission. Am J Psychiatry 2004; 161: 2108-2114.

[27] Fossati A, Feeney JA, Carretta I, et al. Modeling the relationships between adult attachment patterns and borderline personality disorder: The role of impulsivity and aggressiveness. J Soc Clin Psychol. 2005; 24: 520-537.

[28] Scott LN, Levy KN, Pincus AL. Adult attachment, personality traits, and borderline personality disorder features in young adults. J Pers Disord. 2009; 23: 258-280.

[29] Pace CS, Guiducci V, Cavanna D. Attachment in eating-disordered outpatients with and without borderline personality disorder. J Health Psychol. 2016 Mar 18. pii: 1359105316636951. [Epub ahead of print]

[30] American Psychiatric Association. Diagnostic and statistical manual of mental disorders. Fifth edition. DSM-V. American Psychiatric Publishing, Arlington, 2013.

[31] Túry F, Szabó P. Disorders of eating behavior: anorexia nervosa and bulimia nervosa. [A táplálkozási magatartás zavarai: az anorexia nervosa és a bulimia nervosa.] Medicina Könyvkiadó, Budapest, 2000. [Hungarian]

[32] Garner DM, Olmsted MP, Polivy J. Development and validation of a multidimensional eating disorder inventory for anorexia nervosa and bulimia. Int J Eat Disord. 1983; 1: 15-34.

[33] Yager J, Landsverk J, Edelstein CK. A 20-month follow-up study of 628 women. Am J Psychiatry 1987; 144: 1172-1177.

[34] Demetrovics Zs. Drug, family, personality: the psychological background of the individual and the family in the use of various types of drugs. [Drog, család, személyiség. Különböző típusú drogok használatának személyiségpszichológiai és családi háttere.] L'Harmattan Kft., Budapest, 2007. [Hungarian] 
[35] Parker G, Tupling H, Brown LB. A parental bonding instrument. Br J Med Psychol. 1979; 52: 1-10.

[36] Tóth I, Gervai J. Parental Bonding Istrument (H-PBI): The Hungarian version of the Parental Bonding Instrument (PBI). [Szülői Bánásmód Kérdő́ív (H-PBI): A Parental Bonding Instrument (PBI) magyar változata.] Magyar Pszichológiai Szemle 1999; 54: 551-566. [Hungarian]

[37] Radloff LS. The CES-D scale: A self-report depression scale for research in the general population. Appl Psychol Meas. 1977; 1: 385-401.

[38] Spielberger CD, Sydeman SJ. State-trait anxiety inventory and state-trait anger expression inventory. In: Maruish M. (ed.) The use of psychological testing for treatment planning and outcome assessment. Lawrence Erlbaum Associates, Hillsdale, 1994; pp. 292-321.

[39] Sipos K, Sipos M, Spielberger C. The Hungarian version of the State-Trait Anxiety Inventory (STAI) In: Mérei F, Szakács F (eds.) Pszichodiagnostical Vademecum. [A State-Trait Anxiety Inventory (STAI) magyar változata. In: Mérei F, Szakács F. (szerk.) Pszichodiagnosztikai Vademecum.] Nemzeti Tankönyvkiadó, Budapest, 1998; pp. 123-135. [Hungarian]

[40] Eggert J, Levendosky A, Klump K. Relationships among attachment styles, personality characteristics, and disordered eating. Int J Eat Disord. 2007; 40: 149-155.

[41] Tasca GA, Ritchie K, Balfour L. Implications of attachment theory and research for the assessment and treatment of eating disorders. Psychotherapy 2011; 48: 249-259.

[42] Friedberg NL, Lyddon WJ. Self-other working models and eating disorders. J Cogn Psychother. 1996; 10: 193-202.
[43] Spindler A, Milos G. Links between eating disorder symptom severity and psychiatric comorbidity. Eat Behav. 2007; 8: 364-373.

[44] Díaz-Marsá M, Carrasco JL, Sáiz J. A study of temperament and personality in anorexia and bulimia nervosa. J Pers Disord. 2000; 14: 352-359.

[45] Fossati A, Acquarini E, Feeney JA, et al. Alexithymia and attachment insecurities in impulsive aggression. Attach Hum Dev. 2009; 11: 165-182.

[46] Corstorphine E, Waller G, Lawson R, et al. Trauma and multiimpulsivity in the eating disorders. Eat Behav. 2007; 8: 23-30.

[47] Szalai TD. Cognitive-behavioral and attachment interventions in the transdiagnostic treatment of bulimia nervosa and binge eating disorder. Mentálhigiéné és Pszichoszomatika 2016; 17: 353-375.

[48] Levy KN, Meehan KB, Kelly KM, et al. Change in attachment patterns and reflective function in a randomized control trial of transference-focused psychotherapy for borderline personality disorder. J Consult Clin Psychol. 2006; 74: 1027-1040.

[49] Gross JJ. The emerging field of emotion regulation: An integrative review. Rev Gen Psychol. 1998; 2: 271-299.

[50] Gross JJ, John OP. Individual differences in two emotion regulation processes: implications for affect, relationships, and wellbeing. J Pers Soc Psychol. 2003; 85: 348-362.

(Szalai Tamás Dömötör, Budapest, Nagyvárad tér 4., 1089 e-mail: szalai.domotor@gmail.com)

\section{NOTA \\ Új fejlesztés az egészségügyben dolgozók, tanulók részére!}

A magyar nyelvứ szakirodalmi keresőszolgáltatás

\section{Mi a NOTA? \\ Napivizit Orvosi Tudástár Alkalmazás}

Mit tud a NOTA portál?

Megkönnyíti a magyar nyelvű szakirodalmi források keresését.

Eszköztöl függetlenül, akár okostelefonról, a betegágy mellett állva is használható.

\section{Miben kereshet a NOTA-val?}

Az Akadémiai Kiadó folyóirataiban: Orvosi Hetilap, Magyar Sebészet, Mentálhigiéné és Pszichoszomatika.

Más kiadók magyar nyelvű

szakfolyóirataiban: pl. Lege Artis Medicinae, Hypertonia és Nephrologia, Ideggyógyászati Szemle.

A hatályos szakmai irányelvekben.

Magyar nyelvű kérdésekre adott angol nyelvű találatokban, a PubMeden.

\section{nota.hu}

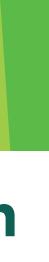
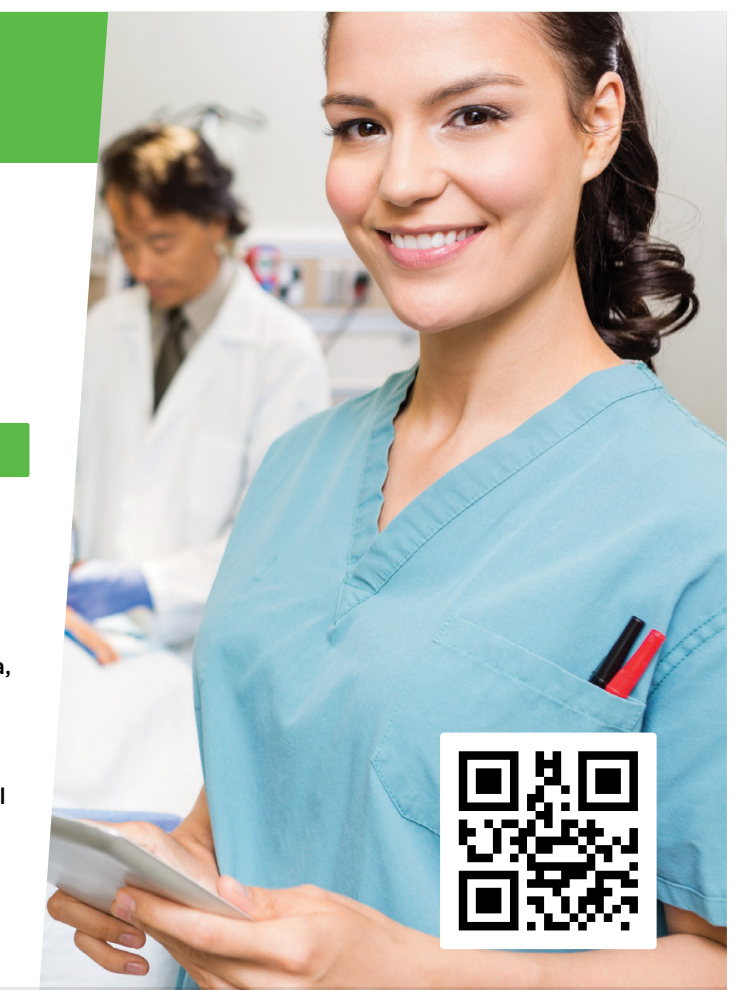

\section{Akadémiai Kiadó}

A Wolters Kluwer Csoport tagja

1117 Budapest, Prielle Kornélia u. 21-35. / Telefon: (1) 464-8246

www.akademiai.hu / www.akademiai.com
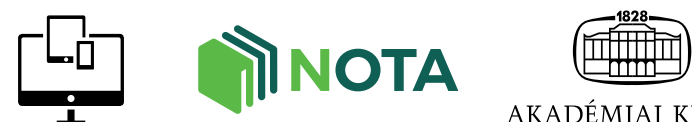

AKADÉMIAI KIADÓ 